\title{
Board Characteristics and Capital Structure of Malaysia Consumer Products Sector
}

\author{
Kuah Yoke Chin*
}

Universiti Tunku Abdul Rahman, Malaysia

Zuriawati Zakaria

Universiti Tunku Abdul Rahman, Malaysia

*Corresponding author: Kuahyc@utar.edu.my

\section{A R T I C L E I N F O}

Article history:

Received 29 January 2018

Revised form 10 April 2018

Accepted 25 April 2018

Keywords:

Board size, Board independence, Board meeting, Capital structure.

\section{A B S T R A C T}

This study investigated the relationship between board characteristics and capital structure, namely total debt, short-term debt, and long-term debt of firms in the Malaysian consumer products sector for the period 2010 to 2014. Based on 109 firms selected for the study, the firms' decision about capital structure regardless of total debt, short-term debt or long-term debt is not influenced by the size of the board. However, if the board membership constitutes more independent directors, the proportion of short-term debt is even higher than the long term-debt. Board meetings were found to have a significantly negative influence on firms' decisions concerning total debt financing. The findings also revealed that large firms hold more short-term and long-term debts when there is an increase in the number of members on the board. The firms that have been long in existence focused more on short-term debt financing and their growth in terms of capital expenditure. Consequently, the total debt of the firms also increased. 


\section{Introduction}

Firms' capital structure consists of debt and equity financing (Ranti, 2013). Capital structure decisions made by finance managers include investments, financing and investment opportunities. The optimal choice capital structure is one that provides the highest rate of returns and the lowest costs to meet the requirements of its various stakeholders (Heng, Azrbaijani \& San, 2012).

The decisions regarding firm's financing are influenced by the board of directors and in fulfillment of the Corporate Governance Code of Practices. The effectiveness of the board in monitoring the management behaviors could directly or indirectly improve the firm's ability to access debt financing. In fact, previous literature (e.g. Ferris, Jagannathan, \& Pricthard, 2003; Lin, Pope, \& Young, 2003) suggest that as protection against agency problems, lenders also consider the manner the board monitors management behavior prior to extending loans. Strong pressures from the board of directors lead managers to pursue a lower leverage (Berger \& Lubrano, 2006). However, if a board consists of more independent directors, the firm would experience a high leverage (Berger, Ofek, \& Yermack, 1997). The occurrence of agency problems and the possibility of managers executing for personal interests necessitates the presence of independent boards to mitigate such issues (Heng et al., 2012).

As the board of management acts on behalf of the shareholders, the evaluation on board composition would ensure that it is able to help the company achieve the maximum benefits with its leadership. According Fosber (2012), short-term debt has characteristics that are similar to the characteristics of longterm debt. However, characteristics of the board of management such as board size, board independence and board meeting will influence the company's choice of capital structure especially the short-term, long-term and total debt financing, since the board of directors are well informed about the firm's condition compared to the shareholders. Therefore, it should help firms to maximum returns and reduce costs associated with alternative sources of finance (Njuguna \& Obwogi, 2015). According to the Malaysian Code on Corporate Governance (MCCG) 2012, the efficacy of the company structure can be optimized with the existence of board governance to control the agency problems which arise from adverse selection and moral hazards. In Malaysia, the number of independent directors shows an upward trend (Germain et al., 2014) due to an increased scale of the company and complexity of the business operation.

The linkage between board characteristics and the structure of capital finance decisions of Malaysian listed companies has not been fully explored and could serve as very crucial and important information for the viability of firms. As reported by MSWG, selective consumer products such as tobacco, breweries, and food and beverage are considered more elastic to recession. The growth of 
the Malaysian population created further demands for goods and services, which are necessities for every household and became the second largest contributor in Malaysia's gross domestic products (GDP) in 2013. Therefore, this study attempted to examine this linkage in listed consumer product companies in Malaysia. The findings of this study could be very vital and helpful for ensuring the sustainability of Malaysian-listed consumer product companies in the global market.

\section{Literature Review}

\subsection{Capital Structure Theories}

The pecking order theory assumes that the company chooses its capital structure based on its preferences. The first resort to funding is internal finance, which refers to retained earnings, followed by debt and lastly equity. The pecking order theory, created by Myers and Majluf (1984), is based on two prominent assumptions. The first is that managers or insiders of the corporation have asymmetric information regarding the issuance of new equity. The second assumption is that managers work for the best interests of existing shareholders. In essence, internal funds such as retained earnings would be used first before other sources of funding are accessed. Only if there are insufficient funds from internal sources, the firm would consider external resources such as debt. As a last resort, the firm would endeavor to finance itself through the issuance of new shares. Large firms are a proxy for asymmetric information since they are closely scrutinized by lenders and used more debt capital (Titman \& Wessels, 1988). Large firms relied move on too long-term debt, while short-term debt was mainly used by small firms (Michaelas, Cittenden, \& Poutziouriset, 1999).

The primary version of the trade-off theory arose from an argument over the Modigliani-Miller theorem. According to Myers (1984), a firm sets a target debt-to-value ratio; it gradually moves towards achieving the set target. Modigliani and Miller (1958) argued that the net effect of tax on firm value would be zero when considering both the corporate and personal taxes. The direct cost of distress is relatively smaller to firm value (Warner, 1977) This theory indicates that as opposed to equity financing, firms prefer debt financing as a way of enhancing their profits (Ting \& Lean, 2011). Furthermore, when corporate income tax is taken into account, debt is viewed as a benefit as it shields income from taxes. The trade-off theory signifies the positive influence between leverage and profitability, hence it did not support the pecking order theory. However, Frank and Goyal (2009) argued that leverage was unable to increase the firm's profitability due to transaction costs. 


\subsection{Board Characteristics}

\subsubsection{Board size}

The board of directors is responsible for monitoring the firm business operations. Abor (2007), Kajanantahn (2012), Florinta (2013) and Njuguna \& Obwogi (2015) reported positive connections between the size of the board and the firm's decision on capital structure in terms of short-term debt, long-term debt and total debt. This suggests that larger boards adopt high debt policy to raise the value of the company. Firms with a high level of debt ratio require greater monitoring to prevent misuse of funds. Hence, they need more members on their board (Jensen, 1986; Wen, Rwegasira, \& Bilderbeek, 2002; Coles, Daniel, \& Naveen, 2008). Firms with large boards experience lower costs of debt (Anderson, Mansi, \& Reeb, 2004).

Interestingly, Ranti (2013) found that firms with weak corporate governance and small board size tend to incur more debt to reduce agency problems. Meanwhile, Heng et al. (2012) showed that members on the board of leading Malaysian non-financial companies play an important role in influencing the firms' financial decisions. The authors revealed that firms with large board size often adopt a policy of low debts. To enhance the firms' performance, large boards might actively pressure managers to adopt lower gearing levels (Butt \& Hasan, 2009). Therefore the hypotheses postulated in this study were:

$\mathrm{H}_{1 \mathrm{a}}:$ Board size affects the use of total debt.

$\mathrm{H}_{1 b}$ : Board size affects the use of short-term debt. $\mathrm{H}_{1 \mathrm{c}}$ : Board size affects the use of long-term debt.

\subsubsection{Board independence}

The relationship between board independence and capital structure has been explored by previous researchers but the results are varied. Njuguna and Obwogi (2015) showed that there is a positive and significant relationship between board independence and capital structure in East African listed companies. This implies that an increase in independent directorship leads to an increase in firm's capital structure. Heng et al. (2012) found that leading companies with high debt policy usually have more independent directors on the board.

On the contrary, Stephanus, Anastasia, and Toto (2014) concluded that there is an inverse relationship between the presence of independent directors on the board and debt ratio. These signal that firms are now more aware that good corporate governance exists with higher independent directors on the boards. Board independence is a substitute for short-term debt (Fama, 1980). With 
an effective independent board, debt holders might not have to supervise the managers closely via the debt as it is of short-term maturity. However, Florinta (2013) indicated that debt decision is not influence by board independence. This is similar to the findings of Butt and Hasan (2009) who revealed that board independence is unable to influence corporate financing behavior. Therefore, taking into consideration the arguments above, the hypotheses for board independence were:

$\mathrm{H}_{2 \mathrm{a}}$ : Board independence affects the use of total debt.

$\mathrm{H}_{2 \mathrm{~b}}$ : Board independence affects the use of short-term debt.

$\mathrm{H}_{3 \mathrm{c}}$ : Board independence affects the use of long-term debt.

\subsubsection{Board meeting}

Board of directors' meetings are the number of regular meetings held by the board during each fiscal year. The meetings refer only to those held in person, excluding telephone meetings. According to Kajananthan (2012), frequent board meetings could result in companies relying more on debt financing, taking advantage of the external source of capital for modernization, expansion and aggressive exploitation of investment opportunities. On the other hand, Stephanus et al. (2014) found that board meeting frequency is significantly negatively associated with debt ratio. The frequency of board meetings could cause an increase in the firm's expenses, time and administrative support requirements (Vafeas, 1999). A firm's resources could be channeled into less productive activities. However, Priya and Nimalathasan (2013) and Velnampy and Nimalthasan (2013) reported that board meeting is not related to firm capital structure decision. The hypotheses proposed for this study were:

$\mathrm{H}_{3 \mathrm{a}}$ : Board meeting affects the use of total debt.

$\mathrm{H}_{3 \mathrm{~b}}$ : Board meeting affects the use of short-term debt.

$\mathrm{H}_{3 \mathrm{c}}$ : Board meeting affects the use of long-term debt.

\subsection{Firm Characteristics}

\subsubsection{Firm age}

A non-monotonic relationship between firm age and debt financing was found in 177 listed firms on the Johannesburg Stock Exchange for the period 1999 to 2009 (Ezeoha \& Botha, 2012). During the startup stage, debt financing is the critical funding source to sustain the firm's business. The need for debt slowly reduces during consolidation, but the usage steadily increases during the maturity stage. 
The high usage of debt financing during the startup and maturity stages is caused by the heavy investment in assets. External creditors accept investment in assets as collateral for debt financing. The higher the collateral value, the lesser the constraint the firms face on borrowing and have greater access to medium-term and long-term debts. Using the number of years since formation as a measure of a firm's age, Archer and Faerber (1966) found a positive and significant effect of firm's age on leverage. The positive effect could also be seen in the three stages of a firm's life cycle, namely growth, maturity and decline (Zare, Farzanfar, \& Boroumand, 2013).

\subsubsection{Firm size}

Large firms are less likely to become bankrupt as they are more diversified and thus, probably highly leveraged (Gruber \& Warner, 1977; Ang, Chua, \& McConnell, 1982; Koksal \& Orman, 2015). Based on the study of 167 firms for the period 1989 to 1998 , Wanzenried (2002) reported that as firms' size increased, on the average $16 \%$ of British and continental firms financed their assets through external long term-debt while European firms funded their capital through banks. Large firms have the capacity to borrow long-term debt given the diversified portfolios unlike small firms which are viewed as risky by investors. Large-and medium-size firms follow the pecking order theory (Frank \& Goyal, 2003).

\subsubsection{Firm growth}

High growth firms tend to issue more debt with increase in their retain earnings (Pandey, 2001). High growth opportunities would cause firms to expand their fixed assets. As a result, firms need to shift the form of financing from new equity to debt in order to reduce agency problems. The positive effect of growth opportunities on leverage is due to covenant protection (Billett, King, \& Mauer, 2007). Debt covenants provide protection for debt holders in high growth firms. However, the earlier findings of Titman and Wessels (1988) indicated that growth is negatively related to the firm's debt financing. Using R\&D expenses as a measure of growth opportunities, they claimed that it is capital assets that add value to a firm. However, capital assets cannot be used as collaterals since it takes time to generate income. Therefore, firms struggle to acquire external financing.

\subsubsection{Firm profitability}

Consistent with the pecking order theory, Koksal and Orman (2015) found that the firms' profitability is negatively related to debt ratio. If large internal source 
of funds are available, firms would hold less external financing. Due to the lower risk of equity financing, when the level of firm's profits increase, they prefer equity financing in terms of retained earning instead of debt financing (Bauer, 2004; Huang \& Song, 2005; Wahab et al., 2012; Khan, Jan, \& Khan, 2015).

\section{Methodology}

This study intended to investigate the relationship between board characteristics and capital structure of listed consumer product companies in Malaysia. The sample constitutes 109 consumer product companies listed in the Kuala Lumpur Stock Exchange (KLSE) for period 2010 to 2014. The data of the board structure, namely board size, board independence and board meeting were obtained from the firm's annual report. Bloomberg database was used to gather information for capital structure (total debt, short-term debt, and long-term debt) and firm characteristics (firm size, firm age, growth and ROA).

During the period of the study, 124 consumer product firms were listed on the Main Board. In order to analyze the impact of board characteristics and firm characteristics on capital structure, this study only took into account firms that had complete data. Therefore, the final sample of this study comprised 109 firms (545 observations). The measurements used for this study are shown in Table 1.

The finding regarding the impact of board characteristics on capital structure is presented based on panel data analysis. According to Baltagi (2005), panel data has greater efficient econometric estimation, that is, it is more informative, shows viability and collinearity among the variables with greater degree of freedom. Unlike the time series analysis which is plagued with multicollinearity, panel data analysis is able to handle large observations with improved accuracy of a model's parameter estimates due to a high degree of freedom (Hsiao, 1986).

This study further examined the impact of board governance and firm characteristics on capital structure based on firm size. Firm size in this study was classified to small (market capitalization less than RM1billion) and large firms (market capitalization more than RM1billion).

The model specifications used for this study are as follows.

$$
\begin{aligned}
& T D R=\alpha+\beta_{1} * \log \left(B_{-} \text {Size }\right)+\beta_{2} * B_{-} \text {Indepen }+\beta_{3} * \log \left(B_{-} \text {Meeting }\right)+ \\
& \beta_{4} * \log \left(F_{-} \text {Age }\right)+\beta_{5} * F_{-} \text {Size }+\beta_{6} * \operatorname{CapExp}+\beta_{7} * R \& D+\beta_{8} * R O A+\varepsilon
\end{aligned}
$$


$S T D=\alpha+\beta_{1} * \log \left(B_{-}\right.$Size $)+\beta_{2} * B_{-}$Indepen $+\beta_{3} * \log \left(B_{-}\right.$Meeting $)+$

$\beta_{4} * \log \left(F_{-}\right.$Age $)+\beta_{5} * F_{-}$Size $+\beta_{6} * \operatorname{Cap} \operatorname{Exp}+\beta_{7} * R \& D+\beta_{8} * R O A+\varepsilon$

$\operatorname{LTD}=\alpha+\beta_{1} * \log \left(B_{-}\right.$Size $)+\beta_{2} * B_{-}$Indepen $+\beta_{3} * \log \left(B_{-}\right.$Meeting $)+$

$\beta_{4} * \log \left(F_{-}\right.$Age $)+\beta_{5} * F_{-}$Size $+\beta_{6} * \operatorname{CapExp}+\beta_{7} * R \& D+\beta_{8} * R O A+\varepsilon$

Where $\alpha=$ constant term; TDR $=$ Total Debt Ratio; STD $=$ Short Term Debt Ratio, LTD = Long Term Debt Ratio. Board Characteristics: B_Size = Board Size; B_Indepen = Board Independence and B_Meeting = Board Meeting. Firm Characteristics: F_Age = Firm Age; F_Size $=$ Firm Size CapExp $=$ Capital Expenditure Ratio, $\mathrm{R} \& \mathrm{D}=\mathrm{R} \& \mathrm{D}$ Expenditure and $\mathrm{ROA}=$ Return on Assets.

Table 1. Variable and Measurement

\begin{tabular}{|c|c|}
\hline Variables & Measurement \\
\hline \multicolumn{2}{|l|}{ Capital Structure } \\
\hline Total debt ratio & Total debt to total assets \\
\hline Short-term debt ratio & Total short-term debt to total assets \\
\hline Long-term debt ratio & Total long-term debt to total assets \\
\hline \multicolumn{2}{|l|}{ Board Characteristics } \\
\hline Board size & Log (total number of directors on the board) \\
\hline Board independence & Number of independent directors to total directors \\
\hline Board meetings & Log (number of board of directors' meetings) \\
\hline \multicolumn{2}{|l|}{ Firm Characteristics } \\
\hline Firm size & Log(firm's market capitalization) \\
\hline Firm age & Log (number of years since firm was established) \\
\hline Firm growth & $\begin{array}{l}\text { 1) Capital expenditure ratio: cash from operations to Capital } \\
\text { expenditure } \\
\text { 2) } R \& D \text { expenditure ratio: } R \& D \text { expenses to revenue }\end{array}$ \\
\hline Firm profitability & Net Income to total assets \\
\hline
\end{tabular}

\section{Finding}

\subsection{Descriptive Statistics}

Table 2 provides the descriptive statistics of the variables used in this study for the period 2010-2014. On average (median), the total debt of 109 Malaysian listed consumer product companies was RM233 million (RM61.76 million). Large 
companies with market capitalization of more than RM1 billion recorded higher average total debt of RM1.15 billion compared to small companies (market capitalization of less than RM1 billion) with an average of RM106 million. An approximation of short-term debt, on the average (median) was RM173 million (RM48.48) million for all companies, while RM82.5 million (42.17 million) and RM827 million (RM652 million) for small and large companies, respectively. Meanwhile, the average long-term debt for small companies was RM7.88 million and RM58.49 million for large companies.

Panel B summarizes the board structure of consumer product companies. The average board size was 7 members. Large companies had more members on the board with an average of 8 members and small companies with 7 members. This is inconsistent with Lipton and Lorsch (1992), who suggested that a company should have eight or nine members for ideal monitoring, with the maximum being 10 members. Board independence for both company sizes was almost similar with 3 members. The small companies approximately held 5 annual board meetings while large companies had 6 annual board meetings. It is evident that consumer product companies in Malaysia adhere to the Bursa Malaysia Listing Requirement (2001) and the Malaysian Code of Corporate Governance (2007) which require at least two directors or one-third of the board members to be independent directors.

As for firm characteristics, the 109 consumer product companies in this study have been in existence for an average of 14 years with the large companies averaging 25 years. The capital expenditure ratio for large companies was higher compared to the small-sized companies, averaging $5.15 \%$ and $4.43 \%$, respectively. However, the average $\mathrm{R} \& \mathrm{D}$ ratio for small companies was higher at $0.25 \%$ in contrast to large companies at only $0.06 \%$. In terms of profitability (as measured by ROA), the Malaysian listed consumer product companies showed an average $5.48 \%$ profitability with $3.99 \%$ for small companies and $16.3 \%$ for large companies.

Figure 1 shows the time trend of total debt ratio, short-term debt ratio and long-term debt ratio from 2010 to 2014. The trend encompasses all firms and is separated according to two groups, that is, small and large firms. Panel A indicates the downward trend in total debt for large firms, with the lowest being in 2013 at $35.5 \%$. Meanwhile, small firms showed an upward trend from $36.84 \%$ in 2010, with the highest total debt ratio recorded in 2013 of $37.92 \%$. However, the trends reversed in 2014, where large firms showed huge increases in debt ratio of about $41.6 \%$. Panel B shows the time trend in short-term debt ratio. The Malaysian consumer product companies showed constant short-term debt ratio for three consecutive years of around $29 \%$. However, a downturn was observed from $30.48 \%$ in 2013 to $28.76 \%$ in 2014 . As for large firms, the usage of shortterm debt reflected a dramatic increase from $24.45 \%$ in 2010 to $33 \%$ in 2014 
compared to small firms that showed a decline to $28.23 \%$ in 2014 from $30.73 \%$ in 2013. Panel C, which graphs the long-term debt ratio, shows opposite and more pronounced trends compared to Panel B. The downward trend of the longterm debt ratio could be observed both in small and large firms. Short-term debt ratio of large firms trended upwards in 2011 to about $28.63 \%$ while the longterm debt ratio declined to $2.08 \%$. Furthermore, the increase from 2013 to 2014 in the long-term debt for small firms from $2.34 \%$ to $2.54 \%$ was supplemented by a decline in the short-term debt ratio of $30.73 \%$ and $28.23 \%$ respectively.

\subsection{The Trend in Capital Structure and Board Structure from 2010 Through 2014}

Figure 2 shows the consumer product sector's board structure time trend from 2010 to 2014. Panel D shows the time trend in board size. The graph shows a declining trend in all firms, especially small firms with market capitalization of less than RM1 billion. Consistent with earlier literature (e.g. Abor, 2007; Kajanantahn, 2012; Florinta, 2013; Njuguna \& Obwogi, 2015), the bigger the size of the company, the more the members employed on the board for monitoring purposes. Panel E indicates that overall, the consumer product sector firms, especially small firms, showed continued increase in the hiring of independent directors to serve on the board, that is, $43 \%$ in 2010 to $46 \%$ in 2014. However, large firms recorded a declining trend during the period 2012 to 2014 . Panel F demonstrates that large firms held more board meetings compared to small firms, with the highest recorded in 2014 of around 6 meetings compared to the previous year of only 5 meetings. 


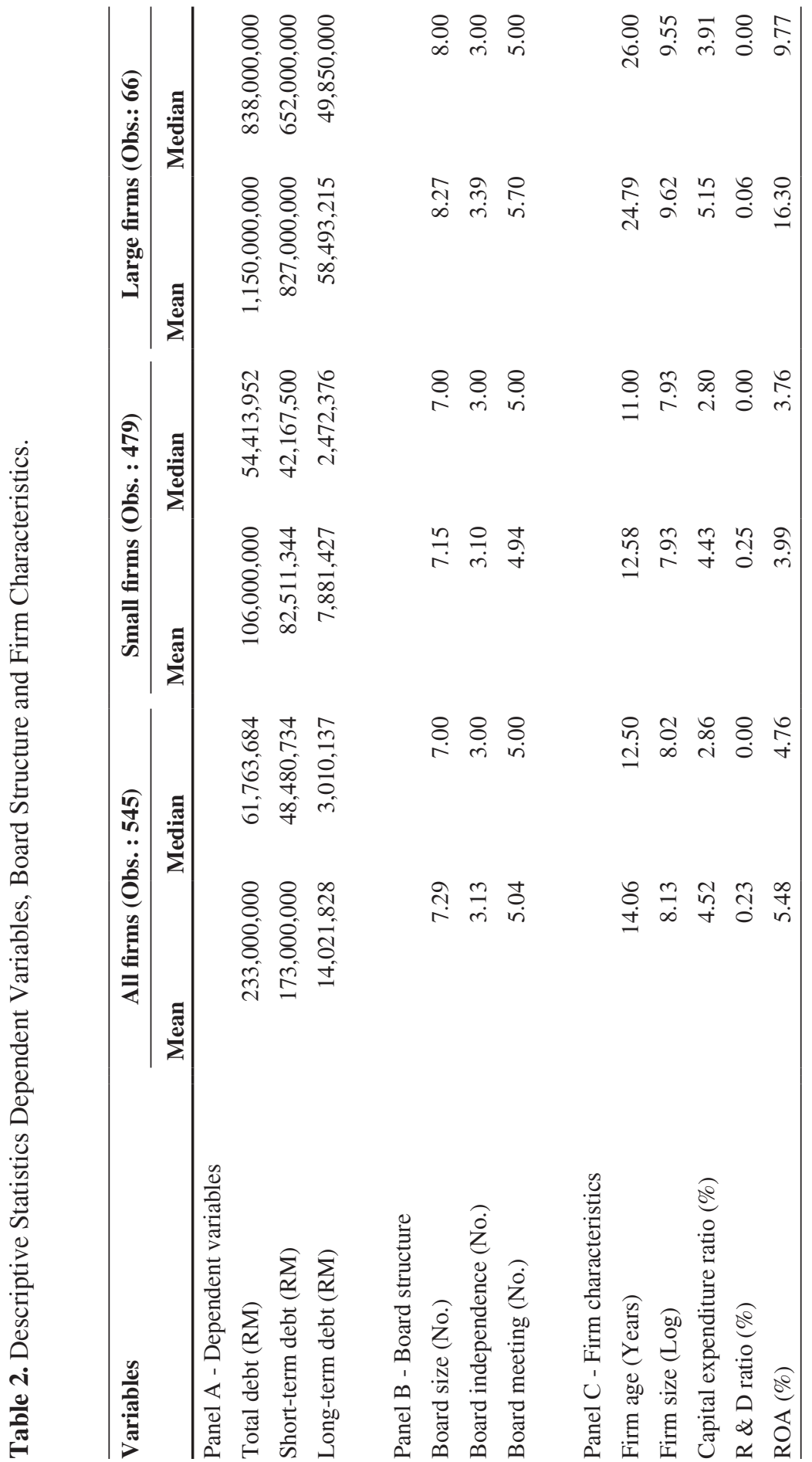



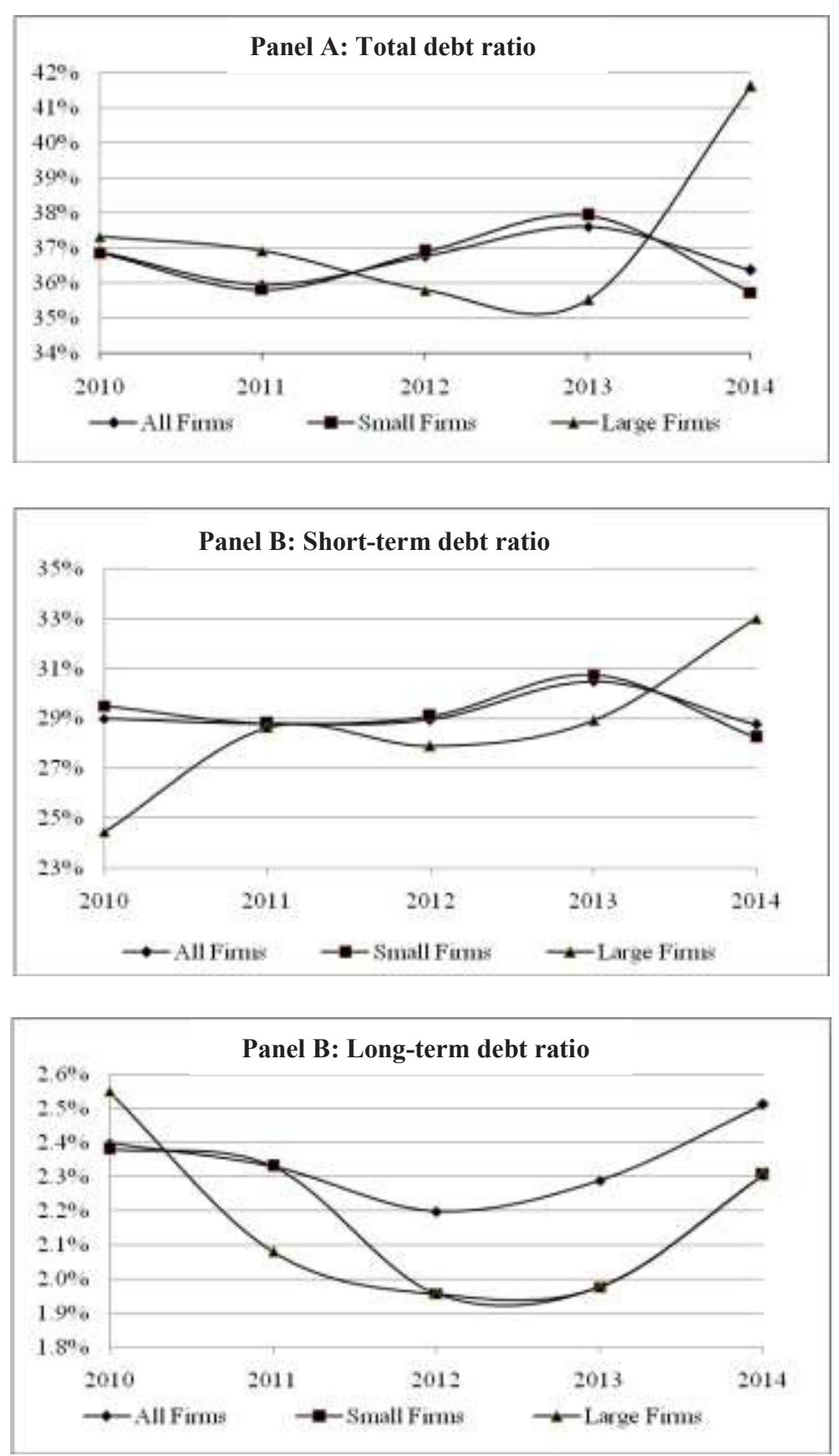

Figure 1. Trend of Capital Structure in Consumer Products Sector. 

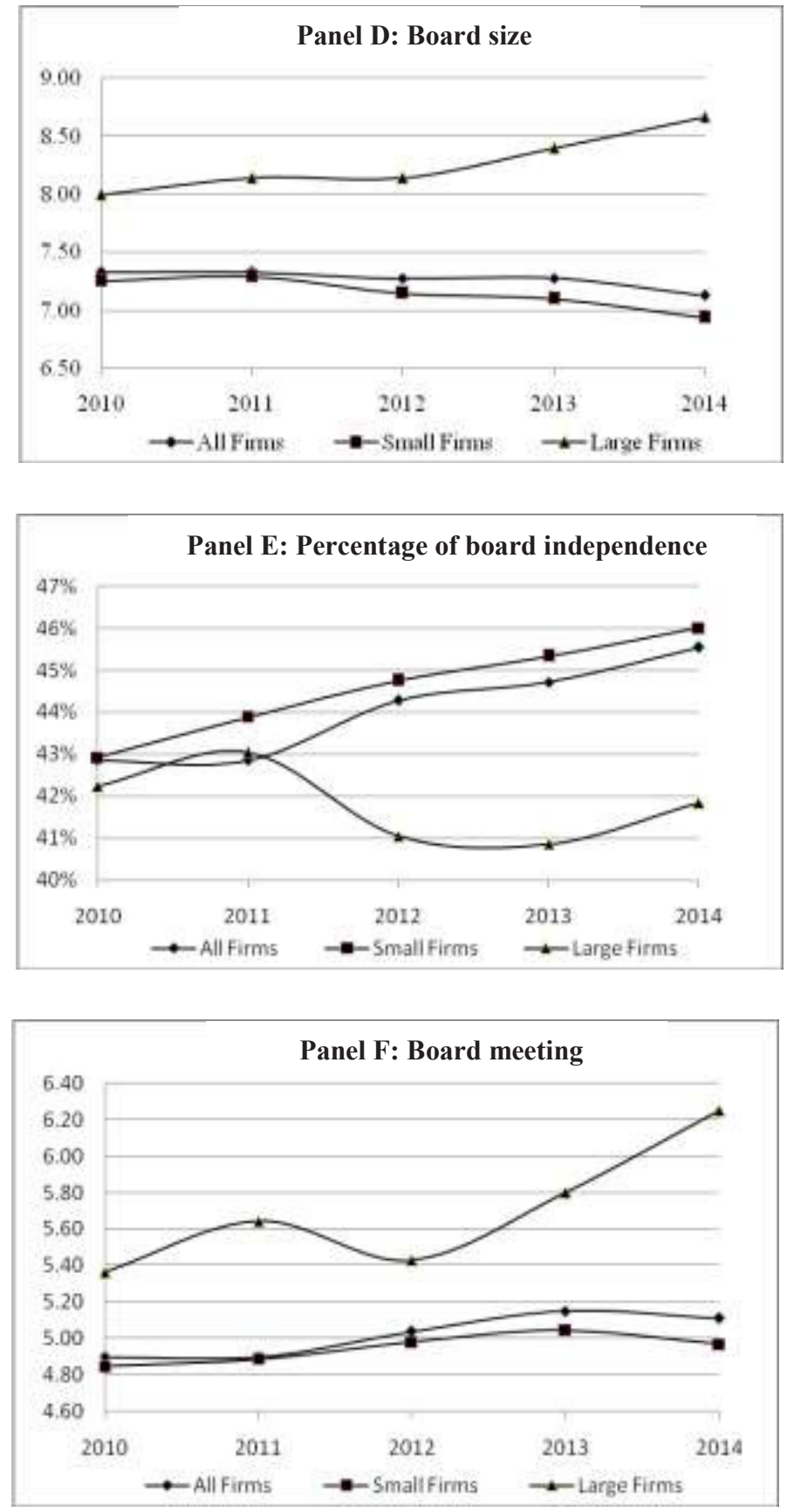

Figure 2. Trend of Board Governance in Consumer Products Sector. 


\subsection{Regression Results}

4.3.1 The relationship between board characteristics and capital structure of malaysian consumer products sector

Table 3. Relationship between Board Characteristics and Capital Structure.

\begin{tabular}{llll}
\hline Variable & \multicolumn{1}{c}{$\begin{array}{c}\text { Total debt } \\
\text { ratio }\end{array}$} & $\begin{array}{c}\text { Short-term } \\
\text { debt ratio }\end{array}$ & $\begin{array}{c}\text { Long-term } \\
\text { debt ratio }\end{array}$ \\
\hline Log (B_Size) & -4.756 & -9.191 & 1.680 \\
B_indepen & $(8.735)$ & $(9.129)$ & $(1.527)$ \\
Log (B_Meeting) & -8.931 & $-15.071 * * *$ & $1.655^{*}$ \\
& $(6.727)$ & 7.030 & $(0.882)$ \\
Log (F_Age) & $-14.282^{* * *}$ & -11.825 & -1.238 \\
& $(6.968)$ & 7.282 & $(1.277)$ \\
F_Size & $14.806^{* * *}$ & $16.325^{* * * *}$ & -0.361 \\
& $(5.509)$ & $(5.758)$ & $(0.826)$ \\
CapExp & $-10.368^{* * *}$ & $-11.887 * * *$ & $0.401 *$ \\
& $(2.576)$ & $(2.692)$ & $(0.236)$ \\
R\&D & $0.311^{* * *}$ & $0.216^{* * * *}$ & -0.015 \\
& $(0.091)$ & $(0.095)$ & $(0.009)$ \\
ROA & $2.036^{* * * *}$ & $2.416^{* * * *}$ & -0.016 \\
& $(0.234)$ & $(0.245)$ & $(0.019)$ \\
\hline R ${ }^{2}$ & $-0.119 * * *$ & -0.050 & -0.003 \\
F-Stat & $(0.040)$ & $(0.042)$ & $(0.003)$ \\
Hausman Test & 0.845 & 0.824 & 0.017 \\
\hline
\end{tabular}

Notes. Log (B_Size) $=$ Board Size; B_indepen = Board Independence; Log (B_Meeting) $=$ Board Meeting; Log $($ F_Age $)=$ Firm Age; F_Size = Firm Size; R\& D = Research and Development; ROA $=$ Return on Equity. $* * *, * *$ and $*$ denote significance at the $1 \%, 5 \%$, and $10 \%$ levels respectively.

The results of equations (1) - (3) are presented in Table 3. To identify the technique that was most suitable, the Huasman test was performed, and the null hypothesis indicated that the random effects technique was better. Table 3 reports the results of total debt ratio and the short-term debt ratio based on the fixed effects model (FEM) and the long-term debt ratio relied on the random effects model (REM).

The firm's capital structure decision was found to be uninfluenced by the size of the board. This finding is consistent with those in the prior literature (e.g. Wen et al., 2002; Ganzeboom, 2014). It reflects the argument with regard to the 
agency theory that firms would rely more on debt to monitor management when they have small boards or are in conflict with large boards. The findings of this study failed to support that of the earlier studies (e.g. Vakilifard, Geraylu \& Yanesari, 2011; Heng et al., 2012; Ranti, 2013; Priya \& Nimalathasan, 2013).

As for independent directors, the findings showed a negative (positive) relationship between the firms' short-term debt (long-term debt) and board independence. The firms' total debt decisions are not affected by board independence. The results of this study reveal that when more independent directors sit on the board, they exert pressure on the management to reduce the short-term debt and increase the long-term debt. This is consistent with the pecking order theory of Myers (1984) and Myers and Majluf (1984) who revealed that firms with large numbers of independent directors on their board have capital structure with large proportion of long-term debt compared to short-term debt. Strong internal monitoring though board independence would lead firms to incur debt with long-term maturity to mitigate debt agency and managerial agency problems (Tosun \& Senbet, 2014). Moreover, the board independence renders reduced the use of short-term debt and increased the use of long-term debt to resolve the firms' free cash flow issues. Enforced payment of cash to service interests on debt would reduce misuse of cash by CEOs for unprofitable investments.

In terms of board meetings, the frequency of board of directors' meetings negatively affects firms' decisions regarding total debt at the $1 \%$ significance level, but does not encompass the maturity tenure. The choice of the longterm or short-term debt by the firms is not influenced by the frequency of board meetings. The higher frequency of board meetings is expected to have greater scrutiny on the firms' continuous ability to service the debt (Jensen, 1993). The greater frequency of meetings among board members would enhance firms' performance (Lipton \& Lorsch, 1992). Therefore, the result of this study suggests that when boards effectively play their role in monitoring the management, it could lead to less dependency of the firm on debt as a source of financing. At the growing stage, the firms should hold more board meetings to discuss and analyze financial matters before making decisions and giving approvals (Myers \& Majluf, 1984).

The findings of this study revealed that the older the consumer product firms in Malaysia, the more they relied on debt financing, especially short-term financing at the $1 \%$ significance level. The age of the firm has a negative and insignificant relationship with long-term debt. Unlike new firm older firms face less adverse selection and moral hazard problems (Huygebaert, 2003). The longer the existence of the firms in the industry, the stronger their reputation, thus facilitating easy access to debt financing (Ezeoha \& Botha, 2012), 
establishing lender-borrower relationship that reduces information asymmetries, and enhancing the efficiency of credit allocation (Sakai, Uesugi \& Watanable, 2010).

Firm size has a negative influence on total debt and short-term debt and a positive influence on long-term debt. It shows that when the size of the firms is large, they tend to have fewer debt sources, especially short-term debt. Larger firms are less likely to face bankruptcy due to their diversified portfolio (Wanzenried, 2002) and have better borrowing capacity relative to smaller firms (Pandey, 2004; Prasad, Green, \& Murinder, 2003). Smaller firms use more shortterm debt compared to larger firms due to costs associated with issuing debt and equity securities (Titman \& Wessels, 1988). Given lower fixed cost of shortterm debt, small firms prefer to incur short-term instead of long-term debt.

This study employed capital expenditure ratio (CapExp), and research and development ratio (R\&D) as measures of firm growth. Both measures showed that firm growth increased its total debt, mainly short-term debt financing at the $1 \%$ significance level. However, the firm's long term debt financing decisions were negatively and insignificantly affected by firm growth. Investment opportunities make firms match the maturity of their assets and liabilities, and often they prefer to use long-term debt (Bruhn, 2015). However, not all firms endeavor to use long-term debt to finance their growth opportunities. Some firms with good growth opportunity might consider using short-term debt as it could be refinanced easily and frequently to obtain better terms. The findings of this study support those of earlier studies by Bevan and Danbolt (2000), Wanzenried (2002), and Rai and Danilevskaia (2005). According to these authors, high growth would result in incurring high risks if more long-term debt is used. Firm growth is not necessarily profitable and uses more internal equity financing to achieve further growth. If the equity market is underdeveloped, then the firms have no option but to choose debt as source of capital, which is risky. Under such circumstances, the only lenders who could be willing to lend money are the banks through provision of short-term loans.

In terms of profitability, the Malaysian consumer product sector firms show that it is negatively related to total debt at the $1 \%$ significance level. In addition, the results also reveal that firm profitability is insignificant to influence the decisions on short-term or long-term debt financing. This is consistent with the pecking order theory. When firm profits increase, they prefer not to use them to service interest payments. This is also consistent with previous findings of Bauer (2004), Huang and Song (2005), Wahab et al. (2012), Khan, Jan and Khan (2015) which concluded that profitability is negatively correlated to total debt. 


\subsubsection{The relationship between board characteristics and capital structure of malaysian consumer products sector based on size.}

In the initial finding, the size of the firm showed significant relationship with total debt, short- term debt and long-term debt. When the size of the firm is controlled, the results vary across firm size. In Table 4, this study estimated the impact of board governance across two groups, namely small (market capitalization less than RM1billion) and large firms (market capitalization more than RM1billion). Based on the Hausman test, the fixed effects model (FEM) provided statistically better results for the total debt ratio (small firms), short-term debt ratio (small firms) and long-term debt ratio (large firms). While the random effects model (REM) was more suitable for total debt ratio (large firms), short-term debt ratio (large firms) and long-term debt ratio (small firms).

Small size firms with more board members prefer to have the lower portion of the short-term debt and increase financing using the long-term debt. The result is consistent with the earlier finding of Alves, Cauto and Francisco (2014) who revealed that large boards prefer to use long-term debt financing resulting in lower information asymmetry problem. The problem is reduced due to greater voluntary disclosure (Cheng \& Courtenay, 2006). On the other hand, based on this study large size firms tend to increase both short-term and long-term debt when they have bigger boards. As suggested by Alves, Cauto and Francisco (2014) and Coles et al. (2008), the complexity of the firm with greater monitoring requirement could render larger boards to be more or less effective. Therefore, it could lead to mixed financing choices. In addition, the result of this study shows that when small size firms are monitored by more independent directors, they prefer to have less short-term debt and more long-term debt financing. In line with pecking order theory, the efficiency of independent directors would help small firms to shift from the short-term debt to the long-term debt and finally to external equity financing. In contrast, large-size firms would choose to use more short-term debt with an increase in the number of independent directors. Strong boards (more independent directors) would use their power to force the firms to hold more debt, especially short-term debt (Harford, Li, \& Zhao, 2008). As for board meetings, the findings differ from the initial result after controlling for firm size. They show that the frequency of meetings among board members of small size firms is negatively correlated to total debt and long-term debt. However, as for large-size firms, decisions regarding capital structure, either short-term debt or long-term debt, are insignificantly influenced by the number of board meetings. 


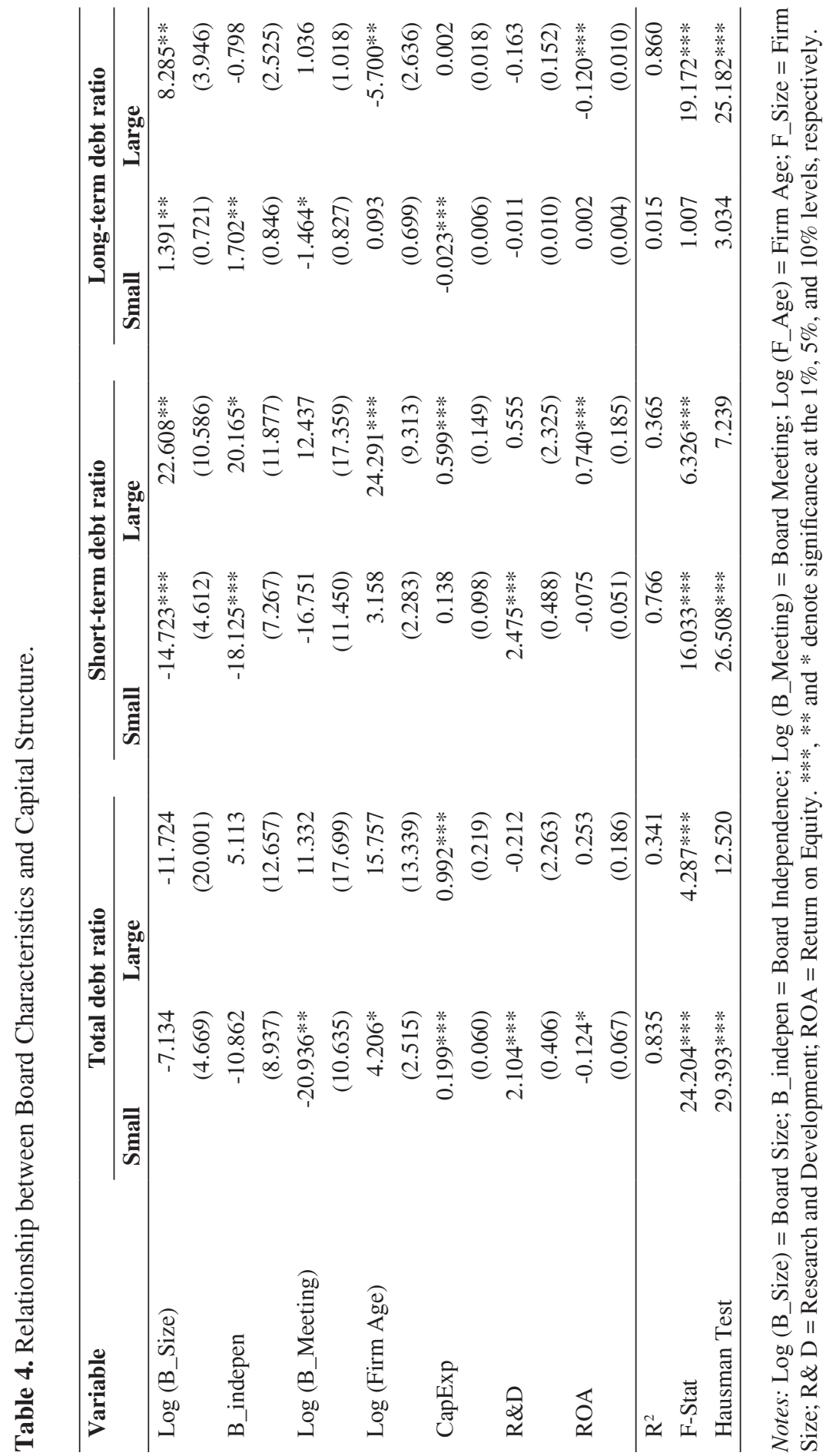


The age of the firm is positively related to total debt of a small-sized firm. The age of the firm is a means to assess the popularity of a business (Diamond, 1989). Older and small-sized firms often have good records and sufficient time to build relationships with lenders and thereby reduce asymmetric information (Berger \& Udell, 1998; Serrasqueiro \& Nunes, 2012). Furthermore, this study also reported that the longer the existence of the large-sized firms, the more they relied on short-term debt instead of long-term debt. They preferred to reduce the usage of long-term debt as a source of their capital. Initial results of both measurements of a firm's growth showed a similar trend, but there were notable differences after controlling for the size of the firm. When firm's growth was measured using capital expenditure ratio (CapExp), the finding showed that it was negatively (positively) related to long-(short-) term debt of small-(large-) sized firms. Using the R\&D ratio, the small-sized firms reported a significant and positive response towards total debt and short-term debt at the $1 \%$ significance level, but it was insignificant in large-sized firms. Large-sized and profitable firms tend to choose higher short-term debt financing and reduce long-term debt at the $1 \%$ significance level.

\section{Conclusion}

The purpose of this paper was to study the impact of board characteristics on the capital structure of consumer product firms listed in Bursa Malaysia, for the five year period from 2010 to 2014. The sample consisted of 109 Malaysian consumer product companies. The research was conducted by using panel data and the sources were the annual reports of the firms. The findings of this study indicated that board size does influence firm's decisions on capital structure after controlling for the size of the firm. Big firms hold large short-term and long-term debts with increases in board membership. If the added member is an independent director, the proportion of short-term debt is even higher than the long-term debt. Small firms, however, move towards long-term debt and reduce short-term debt financing with large boards, especially those constituting more independent directors. Board meetings are negatively related to firms' total debt. In addition, for small firms, the frequency of board meetings caused an increase in the firm's long term debt. Apart from that, the findings also revealed that the longer the Malaysian consumer product firms have existed, the greater their focus on short-term debt financing. After controlling for firm size, firm's growth showed a significant effect on the firm's capital structure. With an increase in the firm's capital expenditure, its total debt tended to increase regardless of the size of the firm. However, if the firm's R\&D increased, small firms incurred more short-term debt financing. 


\section{References}

Abor, J. (2007). Corporate governance and financing decisions of Ghanaian listed firms. Corporate governance: The International Journal of Business in Society, 7(1), 83-92.

Alves, P., Couto, E., \& Francisco, P. (2014). Board of directors' composition and financing choices. Retrieved from https://mpra.ub.uni-muenchen.de/ id/eprint/52973

Anderson, R. C., Mansi, S. A., \& Reeb, D. M. (2004). Board characteristics, accounting report integrity, and the cost of debt. Journal of Accounting and Economics, 37(3), 315-342.

Ang, J. S., Chua, J. H., \& McConnell, J. J. (1982). The administrative costs of corporate bankruptcy: A note. The Journal of Finance, 37(1), 219-226.

Archer, S. H., \& Faerber, L. G. (1966). Firm size and the cost of externally secured equity capital. The Journal of Finance, 21(1), 69-83.

Baltagi, B. H. (2005). Econometric analysis of panel data (3rd ed.). New York: John Wiley.

Bauer, P. (2004). Determinants of capital structure: Empirical evidence from the Czech Republic. Czech Journal of Economics and Finance (Finance a uver), 54(1-2), 2-21.

Berger, P. G., Ofek, E., \& Yermack, D. L. (1997). Managerial entrenchment and capital structure decisions. The Journal of Finance, 52(4), 1411-1438.

Berger, A. N., \& Udell, G. F. (1998). The economics of small business finance: The roles of private equity and debt markets in the financial growth cycle. Journal of Banking \& Finance, 22(6), 613-673.

Berger, A. N., \& Di Patti, E. B. (2006). Capital structure and firm performance: A new approach to testing agency theory and an application to the banking industry. Journal of Banking \& Finance, 30(4), 1065-1102.

Bevan, A. A., \& Danbolt, J. (2000). Dynamics in the determinants of capital structure in the UK.

Billett, M. T., King, T. H. D., \& Mauer, D. C. (2007). Growth opportunities and the choice of leverage, debt maturity, and covenants. The Journal of Finance, 62(2), 697-730.

Bruhn, M (2015), Firm's use of long-term finance: Why, how, and what to do about it? http://blogs.wordbank.org [Retrieved on 08/23/2016].

Butt, S. A., \& Hasan, A. (2009). Impact of ownership structure and corporate governance on capital structure of Pakistani listed companies. International Journal of Business and Management, 4(2), 50-57.

Cheng, E. C., \& Courtenay, S. M. (2006). Board composition, regulatory regime and voluntary disclosure. The International Journal of Accounting,41(3), 262-289. 
Coles, J. L., Daniel, N. D., \& Naveen, L. (2008). Boards: Does one size fit all? Journal of Financial Economics, 87(2), 329-356.

Diamond, D. W. (1989). Reputation acquisition in debt markets. The Journal of Political Economy, 828-862.

Ezeoha, A., \& Botha, F. (2012). Firm age, collateral value, and access to debt financing in an emerging economy: Evidence from South Africa. South African Journal of Economic and Management Sciences, 15(1), 55-71.

Fama, E. F. (1980). Agency problems and the theory of the firm. The Journal of Political Economy, 288-307.

Ferris, S. P., Jagannathan, M., \& Pritchard, A. C. (2003). Too busy to mind the business? Monitoring by directors with multiple board appointments. The Journal of Finance, 58(3), 1087-1111.

Florinita, D. U. C. A. (2013). Board structure and capital structure- Empirical evidence of Romanian listed companies. Revista Romana de StatisticaSupliment-Romanian Statistical Review, 127-132.

Forsberg, R. H. (2012). Determinants of short-term debt financing. Research in Business and Economics Journal, 6, 1.

Frank, M. Z., \& Goyal, V. K. (2003). Testing the pecking order theory of capital structure. Journal of Financial Economics, 67(2), 217-248.

Frank, M. Z., \& Goyal, V. K. (2009). Capital structure decisions: Which factors are reliably important? Financial management, 38(1), 1-37.

Ganzeboom, C. (2014). The influence of ownership concentration and board structure on the capital structure. Evidence from Dutch listed companies. Bachelor's thesis, University of Twente.

Gruber, M. J., \& Warner, J. B. (1977). Bankruptcy costs: Some evidence. The Journal of Finance, 32(2), 337-347.

Harford, J., Li, K., \& Zhao, X. (2008). Corporate boards and the leverage and debt maturity choices. International Journal of Corporate Governance, 1(1), 3-27.

Heng, T. B., Azrbaijani, S., San, O. T. (2012). Board of directors and capital structure: Evidence from leading Malaysian companies. Asian Social Science, 8(3), 123.

Hsiao, C. (1986). Analysis of panel data. Cambridge: Cambridge University Press.

Huang, G., \& Song, F. M. (2005). The financial and operating performance of China's newly listed H-firms. Pacific-Basin Finance Journal, 13(1), 53-80.

Huyghebaert, N. (2003). The capital structure of business start-ups: Policy implications. Tijdschrift voor economie en management, 48(1), 23-46.

Jensen, M. C. (1986). Agency cost of free cash flow, corporate finance, and takeovers. American Economic Review, 76(2). 
Jensen, M. C. (1993). The modern industrial revolution, exit, and the failure of internal control systems. The Journal of Finance, 48(3), 831-880.

Kajananthan, R. (2012). Effect of corporate governance on capital structure: Case of the Sri Lankan listed manufacturing companies. Journal of Arts, Science\& Commerce, 3(4), 63.

Khan, I., Jan, S. U., \& Khan, M. (2015). Determinant of capital structure: An empirical study of cement sector of Pakistan. Asian Journal of Management Sciences \& Education, 4(3).

Köksal, B., \& Orman, C. (2015). Determinants of capital structure: Evidence from a major developing economy. Small Business Economics, 44(2), 255-282.

Lin, S., Pope, P. F., \& Young, S. (2003). Stock market reaction to the appointment of outside directors. Journal of Business Finance \& Accounting, 30(3-4), 351-382.

Lipton, M., \& Lorsch, J. W. (1992). A modest proposal for improved corporate governance. The Business Lawyer, 59-77.

Margaritis, D., \& Psillaki, M. (2010). Capital structure, equity ownership and firm performance. Journal of Banking \& Finance, 34(3), 621-632.

Michaelas, N., Chittenden, F., \& Poutziouris, P. (1999). Financial policy and capital structure choice in UK SMEs: Empirical evidence from company panel data. Small Business Economics, 12(2), 113-130.

Modigliani, F., \& Miller, M. H. (1958). The cost of capital, corporation finance and the theory of investment. The American Economic Review, 48(3), 261-297.

Myers, S. C. (1984). The capital structure puzzle. The Journal of Finance, 39(3), 574-592.

Myers, S. C., \& Majluf, N. S. (1984). Corporate financing and investment decisions when firms have information that investors do not have. Journal of Financial Economics, 13(2), 187-221.

Njuguna, C. W., \& Obwogi, T. N. Relationship between board characteristics and capital structure among companies listed in East Africa. International Journal of Educational Research, 3(1), 355-372.

Pandey, I. M. (2004). Capital Structure, profitability and market structure: Evidence from Malaysia. Asia Pacific Journal of Economics and Business, 8(2), 78.

Prasad, S., Green, C., \& Murinde, V. (2003). Company financial structures in developing economies: Evidence from a comparative analysis of Thai and Malay companies. Working Paper, University of Birmingham.

Priya, K., \& Nimalathasan, B. (2013). Board characteristics and capital structure: A case study of selected hotels \& restaurants in Sri Lanka. International Journal of Advanced Research in Management and Social Sciences, 2(12), 1-13. 
Rai, A., \& Danilevskaia, V. (2005). Choice of short-term and long-term debt in five Eastern European countries. J. Int'l Bus. \& L., 4, 34.

Ranti, U. O. (2013). The effect of board size and CEO duality on firms' capital structure: A study of selected listed firms in Nigeria. Asian Economic and Financial Review, 3(8), 1033.

Sakai, K., Uesugi, I., \& Watanabe, T. (2010). Firm age and the evolution of borrowing costs: Evidence from Japanese small firms. Journal of Banking \& Finance, 34(8), 1970-1981.

Stephnus, R. W, Anastasia, K. N. F. T., \& Toto, R. (2014). The effect of corporate governance on capital structure in public listed companies in Indonesia. Abstract of Emerging Trends in Scientific Research, 1, 1-16.

Serrasqueiro, Z., \& Nunes, P. M. (2012). Is age a determinant of SMEs' financing decisions? Empirical evidence using panel data models. Entrepreneurship Theory and Practice, 36(4), 627-654.

Ting, I. W. K., \& Lean, H. H. (2011). Capital structure of government-linked companies in Malaysia. Asian Academy of Management Journal of Accounting and Finance, 7(2), 137-156.

Titman, S., \& Wessels, R. (1988). The determinants of capital structure choice. The Journal of Finance, 43(1), 1-19.

Tosun, O., \& Senbet, L. W. (2014). Internal control and maturity of debt. WBS Finance Group Research Paper.

Vafeas, N. (1999). Board meeting frequency and firm performance. Journal of Financial Economics, 53(1), 113-142.

Vakilifard, H. R., Gerayli, M. S., Yanesari, A. M., \& Ma'atoofi, A. R. (2011). Effect of corporate governance on capital structure: Case of the Iranian listed firms. European Journal of Economics, Finance and Administrative Sciences, 35, 165-172.

Velnampay, T., \& Nimalthasan, P. (2013). Corporate governance practices, capital structure and their impact on firm performance: A study on Sri Lankan listed manufacturing companies. Research Journal of Finance and Accounting, 4(18), 69-79.

Wahab, R. A., Amin, M. S. M., \& Yusop, K. (2012). Determinants of capital structure of Malaysian property developers. Middle-East Journal of Scientific Research. Hal, 1013-1021.

Wanzenried, G. (2002). Signaling with capital structure revisited (No. dp0214). Universitaet Bern, Department Volkswirtschaft.

Gruber, M. J., \& Warner, J. B. (1977). Bankruptcy costs: Some evidence. The Journal of Finance, 32(2), 337-347.

Wen,Y., Rwegasira, K., \& Bilderbeek, J. (2002). Corporate governance and capital structure decisions of Chinese listed firms. Corporate Governance: An International Review, 10(2), 75-83. 
Zare, R., Farzanfar, F., \& Boroumand, M. (2013). Examining the firm age, size and asset structure effects on financial leverage in the firms listed in Tehran Stock Exchange. International Journal of Economy, Management and Social Sciences, 2(6), 256-264. 